EEC Research Council, now chaired by $\mathrm{Mr}$ Gerald Kaufman from the UK Department of Industry. Its inability to agree on a site for JET, the Community's fusion project, has held up implementation of the four-year joint research programme, most recently because of French insistence that the site be at CERN if not in France itself. The two main contenders are Garching in Germany and Culham in Britain.

The possibility that, with the appointment of $\mathrm{Mr}$ Brunner as both Energy and Research Commissioner, these two sets of linked issues might themselves become linked is not being talked about openly. But $\mathrm{Mr}$ Benn, while pointing out the division of responsibilities between the two Councils, does stress that he is taking a close interest in the subject and affirms that the project is not dead. He could conceivably argue that JET is now to be seen as an energy matter rather than a research project. But for the moment he merely continues to emphasise Britain's view that the Culham site is the most suitable.

\section{JET domino}

In a sense JET is a vital domino in the efforts to stimulate some movement on European energy. Britain for one might find it more difficult to posture over certain aspects of policy if she won JET, although she is highly unlikely to relinquish her self-styled role of remaining Europe's energy equivalent of a 'bread basket' by surrendering sovereignty over North Sea oil and gas.

Yet this idea has been publicly canvassed. It was $\mathrm{Mr}$ Simonet's view at the end of his tenure that Britain should invite other EEC members to join in North Sea exploitation in return for the guaranteed European market she wants even if prices fall: in other words, access to the goods for access to the market. $\mathrm{Mr}$ Benn is fiercely resistant to that suggestion.

$\mathrm{He}$ also resists the notion of dealing with one type of energy investment, in nuclear power for example, without dealing with support for other types. To him there is no trade-off to be made: if Europe is to reduce its dependence on imported energy to some $50 \%$ by 1985 -its intended (if receding) goal-all energy investment must be stimulated.

But even while the haggling goes on over the msp and Euratom loans, the fact remains that Europe will still be the world's largest energy importer in 1985. That, indeed, is why some people say that Europe's nuclear policy, of which the Euratom loans are just one facet, is the most crucial aspect of its energy policy and one which simultaneously offers the best prospect of European cooperation.

The Commission is concerned that the projected nuclear future is now a mere shadow of what it was: the optimistic forecasts of $200 \mathrm{GW}$ of nuclear power by the mid-1980s were reduced to $160 \mathrm{GW}$ some time ago, and according to Simonet the Community would now be lucky to reach $90 \mathrm{GW}$ by then. The problems here, however, stretch beyond mere construction of nuclear power stations.

The EEC countries, all members of Euratom, have so far failed to resolve the now long-standing problem posed by France, which has not signed the Non-Proliferation Treaty, regarding the arrangement for IAEA inspectors to check nuclear installations. France fears IAEA safeguards will be imposed without her consent; her Euratom partners fear she will escape the safeguards they face. One by-product: without agreement on safeguards, a threat to future supplies of enriched uranium from abroad-at a time when at least one of the two European enrichment consortia, Urenco, is facing increasing difficulty.

The issue of reprocessing is still to come on the European front, although reassessment of the matter by the new Carter Administration could have implications for any European intention to reprocess spent fuel on an international basis. $\mathrm{Mr}$ Benn hopes to go to the United States to discuss such matters while Council president, although as a UK minister. But the subject of nuclear fuel supply and the nuclear fuel cycle is only slated to come up in the Council in the second half of 1977.

The work programme for Britain's half of the year includes the subjects of oil refining policy, security of oil stocks, the stockpiling of coal and the use of it in power stations. The Council under Mr Benn may not manage to embrace all these matters as well as make progress on the immediate decisions in the two meetings provisionally planned for April and June.

Past experience of the Council certainly does not offer a happy prognosis. But perhaps the man temporarily at the top can remedy that and confound his critics at the same time. It would indeed be ironic if it was Mr Benn who finally did most to promote European cooperation. That is what is now needed. Matters have reached the stage when the degree to which the old Europeans take Britain seriously over energy policy, and vice versa, is now to be determined.

USA

\title{
An unprecedented debate
}

Colin Norman reports from Washington on the continuing discussions about genetic manipulation experiments in the United States

AfTER seven months of intense and at times acrimonious debate, the City Council of Cambridge, Massachusetts, last week lifted a moratorium it had placed on some uses of the controversial recombinant DNA genetic engineering technique at Harvard and Massachusetts Institute of Technology. Acting on the advice of a citizens' review board, the council has decided to allow the research to go ahead in Cambridge under strict safety controls and under the watchful eye of a committee of the city's residents.
While the debate in Cambridge has been coming to a resolution, however, it has been picking up momentum in many other parts of the United States. A debate without precedent, it is leading in many cases to an unusual degree of citizens' involvement in the conduct of academic and industrial research, and in the view of many could have a profound influence on future relationships between universities and their surrounding communities.

The following are some of the more important developments which have occurred over the past few weeks.

- New York. Legislation to control recombinant DNA research throughout New York state is expected to be introduced into the state legislature this week. If passed unchanged, it could result in the most stringent controls so far adopted anywhere in the United States.

The legislation is a direct result of a public hearing called last October by the State Attorney General's Office, and the bill was drafted by Deborah Feinberg, an aide in the Attorney General's environmental health bureau. The legislation would essentially require that all academic and industrial research laboratories planning to conduct recombinant DNA experiments must apply for a licence from the state Department of Public Health. The Commissioner of Public Health would be empowered to draft state-wide regulations, based on the NIH guidelines but with additional enforcement provisions. Health monitoring of laboratory personnel would be required, for example, and applicants for licences would have to describe their proposed 
monitoring procedures. The health department would also be given power to inspect all facilities conducting recombinant DNA experiments, to ensure that the regulations are being followed. Violations could result in a fine and suspension of the licence.

In a 60-page report accompanying the bill, Feinberg recommends that most recombinant DNA experiments should be conducted in moderate containment laboratories (P3 laboratories under the terms of the NIH guidelines), at least until the potential hazards have been better evaluated. "If it then seems safe and appropriate", she suggested last week, "they could be lowered to P2 or P1". The report is advisory, however; the bill requires the health department to set containment levels for classes of experiments.

- California. Two committees of the California state assembly, the health committee and the committee on energy, environment and natural resources, have been holding public hearings on recombinant DNA at which a number of prominent opponents and proponents of the research ("the recombinant DNA travelling road show", one wit has described them) testified. A bill, drafted by Marc Lappé, an official in the state health department, is under consideration by the committees, but it has not yet been introduced into the legislature.

Lappé said last week that he expects the legislature to approve legislation later this year which would at least make the NIH guidelines applicable to all facilities conducting recombinant DNA research in California. Like the New York legislation, the California bill is also expected to include provisions for health monitoring of laboratory workers and enforcement by the state government. In addition, Lappé said that the bill now under discussion would require principal investigators to obtain informed consent from other laboratory personnel taking part in recombinant DNA research.

- Cambridge. The widely-reported debate over recombinant DNA research in Cambridge is largely responsible for sparking the interest of other city and local governments in the issue. The city council last July imposed a threemonth moratorium (later extended to seven months) on P3- and P4-level experiments at Harvard and MIT, and established a committee of Cambridge citizens to recommend the conditions, if any, under which such research should be permitted in the city. Last month, the committee suggested the P3-level work should be allowed to go ahead in accordance with the NIH guidelines, but with some added precautions. All P3 experiments should be conducted on crippled microorganisms, for example, there should be health monitoring of laboratory workers, and a committee of Cambridge residents should be established to oversee the work, to ensure that the regulations are followed.

Last week, the council rejected, by a vote of 6 to 3, a resolution proposed by Mayor Alfred E. Vellucci to prohibit all P3- and P4-level experiments in Cambridge, and it then voted to implement the committee's recommendations. The vote, which essentially incorporated the recommendations into city ordinances, was widely regarded as an acid test of public acceptability of recombinant DNA research.

- Princeton. Events at Princeton University provide a unique, and in some respects, exemplary record of cautious debate and discussion before proceeding with recombinant DNA research. Nobody at Princeton was involved in developing recombinant DNA techniques, and thus no experiments were under way there before the national debate began. Last year it was decided no recombinant DNA experiments should be permitted at Princeton until the matter had been fully discussed.

Last September, the university established a special biohazards committee, under the chairmanship of ecologist Robert May, to recommend a policy for the university. The committee, which consisted of three biologists and seven people from other disciplines, unanimously approved a report last December which essentially states that the research should be permitted at Princeton, subject to controls more strict than the NIH guidelines. It suggested, for example, that no P4-level work be permitted, that the NIH guidelines be used as a minimum set of requirements for containing modified microorganisms, and that any P3 laboratories built at Princeton should meet more stringent standards.

The report then went to the University Research Board, which endorsed it unanimously and passed it on to the university's President. $\mathrm{He}$ took it to the Council of the Princeton University Community, a group consisting of undergraduates, graduate students, faculty and alumni, which also endorsed it unanimously. The President, William G. Bowen, intended to take the report to the university's trustees, the top governing body, at the end of January, but in the meantime, the local community was brought in. A public meeting organised by officials from the university and from the local township and borough was held to discuss the report, as a result of which a citizens' committee has been established to review the proposals. Bowen is expected to await the findings of that committee before taking the report to the trustees.
- San Diego. After the debate erupted in Cambridge, Mayor Pete Wilson of San Diego invited officials of the University of California at San Diego to meet with him to discuss their plans for conducting recombinant DNA experiments. They informed him of their intent to construct a P3-level laboratory in the new medical school, and invited an aide to the Mayor, Mike Madigan, to sit on the university biohazards committee. Subsequently, the city also established a citizens' committee to review the matter. The committee conducted about six months of hearings, taking testimony from a variety of people from around the United States, and it issued a report last month which is expected to be debated by the city council in the next couple of weeks.

The committee intentionally steered clear of recommending whether or not the work should be allowed to proceed at the university, since the city has little formal jurisdiction over the university. It recommended, however, that more citizens be brought on to the biohazards committee, urged the university to disseminate information on its plans for recombinant DNA research, and suggested that health monitoring of laboratory workers be undertaken.

- Ann Arbor. An intense internal debate took place at the University of Michigan last year over plans to conduct recombinant DNA research there. The university planned to construct P3-level facilities for recombinant DNA research, and it established a committee to review the biological hazards and a second committee, consisting of non-biologists, to look into the social and philosophical implications.

After an extended debate, the committee of non-biologists recommended, with one dissent, that the university should go ahead with its plans, and the Board of Regents, the university's governing body, subsequently endorsed the recommendation by a vote of 6 to 1 .

- Bloomington. A public hearing was held last year by an environmental committee appointed by the Mayor of Bloomington, Indiana, to review plans by the University of Indiana to construct a P3 laboratory for recombinant DNA research. The council has so far taken no action, however, and an aide to the Mayor said last week that city officials plan to keep an eye on events, but no city-level regulation is anticipated at present.

- The federal government. Much of the concern which has been expressed

An oversight meant an error in "Carter's energy problem" (3 February, page 398-399): $\$ 31,400$ million and $\$ 42.000$ million should have read $\$ 314,000$ million and $\$ 420.000$ million, and 100 million and 300 million should have read 1,000 million and 3,000 million. Our apologies. 
in state and local debates on recombinant DNA research stems from the fact that the NIH guidelines do not apply to industry, and are not backed by any enforcement mechanism. In that regard, a little-known committee, established last year by President Ford, could prove influential. The committee, which consists of representatives of a variety of federal agencies, is looking into ways to extend the NIH guidelines to cover all recombinant DNA research in the United States. The committee, which meets in closed sessions, is expected to issue recommendations in mid-March.

According to one participant, a broad consensus has been established in the committee that the NIH guidelines should be transformed into enforceable regulations, but it seems that no existing agency has the power to enforce them. For obvious reasons, NIH doesn't want to be placed in the position of both supporting and regulating the research, and the committee is now debating whether to recommend that several regulatory agencies be given the responsibility jointly, or whether to recommend that
Congress should pass legislation to give the authority to a single agency. The basis of the regulations, in any case, will be the present NIH guidelines.

In the meantime, a bill was introduced into both the House and the Senate last week to establish a federal licensing scheme for recombinant DNA research, which would apply to both industrial and academic research. Drafted by Senator Dale Bumpers of Arkansas, the legislation is designed to enforce the NIH guidelines as a bare minimum. When he introduced the bill, Bumpers said that if he had his choice, "there would be a moratorium declared right now on all recombinant DNA research". Senator Edward Kennedy's health subcommittee is expected to hold hearings on the bill early in April, after the inter-agency committee has issued its proposals.

Underlying a good deal of the concern is a deep suspicion of what industry is intending to do with recombinant DNA technology, and those suspicions have surfaced dramatically in the past couple of weeks following the publication of a proposal by the Department of Commerce to expedite patent applications involving recombinant DNA techniques.

The proposal, drafted by Assistant Commerce Secretary Betsy AnkerJohnson, would require patent applicants to state that they will abide by the NIH guidelines, though they would be permitted to "include an explanation of any deviations (from the guidelines) considered essential to avoid disclosure of proprietary information". That exemption has attracted criticism because it would allow industrial companies to proceed with their research without notifying anybody.

Such criticism last week prompted Joseph Califano, the new Secretary of Health, Education and Welfare, to ask Secretary of Commerce Juanita Kreps to withdraw the proposal. Dr Anker-Johnson pointed out in a telephone interview last week, however, that the proposal in fact forces industry to disclose more information than it is required to under existing regulations. Further disclosure could result in loss of patent rights in many countries which preclude the award of patents on processes for which there has been any prior disclosure.

\section{Guidelines recommended}

Canadians are now discussing guidelines for recombinant DNA experiments. David Spurgeon reports

AN ad hoc committee of Canada's Medical Research Council has presented its recommendations on guidelines for handling recombinant DNA molecules. The guidelines are similar to those adopted by Britain and the United States, although they are designated differently, but they go further in that they include guidelines also for experiments involving animal viruses and cells.

The committee's report was made public recently in a press conference held by the MRC, which is the federal granting agency for medical research in the universities. If adopted, the guidelines will apply to all MRC grantees, but not to industry. A federal interagency committee has been studying the question as it applies to industry. Dr G. Malcolm Brown, the MRC president, said the ad hoc committee's recommendations would be discussed at a meeting of the council near the end of February, when they could be approved, rejected or modified. It is considered almost certain, however, that the council will accept them.

The recommendations were drawn up by a group that included researchers in the appropriate fields and also a member of Queen's University's law faculty. The committee also included a member of the Defence Research Establishment, a member of the University of Alberta's pediatrics department and an observer from the National Research Council.

The Chairman of the committee was Dr Louis Siminovitch, chairman of the department of medical genetics at the University of Toronto and geneticistin-chief at the Hospital for Sick Children. Dr Siminovitch was influential in the MRC decision to include animal viruses and cells in the committee's terms of reference.

At present, no research involving recombinant DNA is being conducted in Canada, but some experiments have been proposed. A total of one-sixth of MRC's grants could be affected by the proposed guidelines, totalling about \$8-10 million a year, because of their effect on animal viruses and cells.

The earliest the recommendations could be put into effect would be April 1 , according to $\mathrm{Dr}$ Brown, but Dr Siminovitch said many precautions have already been introduced. If the guidelines are approved, the MRC will insist that all recommendations for laboratory safety are carried out before granting funds. The mechanism for enforcing guidelines is thus similar to that adopted in the United States, though different from that in Britain.

The guidelines themselves provide for six levels of containment, ranging from a statement of good microbiological laboratory practice (level A), plus suitable containment measures for agents of no known or potential risk, to requirements for very hazardous materials, such as the virus that causes lassa fever (level F). The technique and equipment described cover all aspects of laboratory research, including the design of laboratories, treatment of effluents, protective clothing and handling of animals.

In the section on recombinant DNA molecules, biological containment methods involving the use of strains of viruses and bacteria that have been altered so that they will not survive outside the laboratory, are included. In the section on cells and viruses, viruses known to cause infectious diseases, and those known or thought to be associated with cancer, are classified according to risk on the basis of their infectivity for man, and also for animals, the severity of the disease they cause, and the range of animals they can infect. Various factors, such as the type of cell, culture conditions, and the manipulations involved, are used to assign the various experiments with animal cells in culture to the containment levels described. Three levels of responsibility are described: the prin- 